\title{
EVALUASI OPERASIONAL ANGKUTAN UMUM PENUMPANG TRAYEK L1 KOTA BANYUWANGI
}

\section{Operational Evaluation of Public Route L1 Banyuwangi City}

\author{
Khoirul Abadi ${ }^{1}$, Athoillah Burhanuddin ${ }^{2}$ \\ ${ }^{1}$ Jurusan Teknik Sipil Fakultas Teknik Universitas Muhammadiyah Malang \\ ${ }^{2}$ Alumni Teknik Sipil Fakultas Teknik Universitas Muhammadiyah Malang \\ Kampus III Jalan Raya Tlogomas No. 246 Telp (0341) 464318 psw 176 Malang 65144 \\ E-mail: athoillah.burhanuddin53@gmail.com
}

\begin{abstract}
Public transport passengers in the city of Banyuwangi L1 total number of registered fleet operates that is 32 units. Based Banyuwangi regent regulation No. 24 of 2014, public transportation passengers away near Rp. 5000 for public passenger and Rp. 3000 for passenger uniformed students. Public transport passengers Brawijaya Route L1 Terminal Terminal Blambangan (Via Jl. Jend. A. Yani) operates the average - average 5 times roundtrip $(P P)$ or 10 trips a day trip. The purpose of this study to determine the performance of public transport passengers L1, method used in this study adopts the methods of the Technical Guidelines for the Implementation of Public Transport in Cities in Fixed These and Regular (Directorate General of Land Transportation 2002). The study results public passenger transport performance trajectory L1 year 2105, the average Load factor of $48,33 \%$, the average frequency of 26,17 vehicle/hour, average headway time of 2,46 minutes, average travel time of 3,17 minute/ $\mathrm{km}$ with average travel speed of 19,30 $\mathrm{km} / \mathrm{hour}$.
\end{abstract}

Keywords: Public Transport Passenger, Performance evaluation

\begin{abstract}
Abstrak
Angkutan umum penumpang di kota Banyuwangi Trayek L1 Jumlah total armada beroperasi yaitu 32 unit. Berdasarkan peraturan Bupati Banyuwangi Nomor : 24 tahun 2014, tarif angkutan umum penumpang jauh dekat Rp. 5000 untuk penumpang umum dan Rp. 3000 untuk penumpang pelajar berseragam. Angkutan umum penumpang Trayek L1 Terminal Brawijaya Terminal Blambangan (Via Jl. Jend. A. Yani) beroperasi rata - rata 5 kali pulang pergi (PP) atau 10 rit perjalanan setiap harinya. Tujuan studi ini untuk mengetahui operasional Angkutan umum penumpang L1, Metode yang digunakan dalam studi ini metode mengadopsi dari Pedoman Teknis Penyelenggaraan Angkutan Penumpang Umum di Wilayah Perkotaan dalam Rute Tetap dan Teratur (Direktorat Jendral Perhubungan Darat 2002). Hasil studi kinerja angkutan umum penumpang trayek L1 tahun 2105, Load factor rata-rata 48,33\%, frekuensi rata-rata $26,17 \mathrm{kend} / \mathrm{jam}$, headway waktu rata-rata 2,46 menit, waktu tempuh rata-rata 3,11 menit/km dengan kecepatan tempuh rata-rata $19,30 \mathrm{~km} / \mathrm{jam}$.
\end{abstract}

Kata Kunci : Angkutan Umum, Penumpang, Evaluasi Kinerja.

\section{PENDAHULUAN}

Kota Banyuwangi yang memiliki luas $5.782 \mathrm{~km}^{2}$ yang terbagi atas 24 kecamatan. Penduduk Kabupaten Banyuwangi pada periode februari 2014 sudah mencapai 1.600.000 jiwa (sumber : Dinas Kependudukan dan Pencatatan Sipil Kota Banyuwangi).Angkutan Umum penumpang di kota Banyuwangi memiliki 12 jaringan trayek, Trayek L1 Jumlah total armada beroperasi yaitu 32 unit.
Panjang trayek $\mathrm{L} 1 \pm 18 \mathrm{~km}$, waktu operasional pukul $06.00-21.00$ WIB. Berdasar peraturan Bupati Banyuwangi Nomor : 24 tahun 2014, tarif angkutan umum penumpang jauh dekat Rp. 5000 untuk penumpang umum dan Rp. 3000 untuk penumpang pelajar berseragam. Angkutan umum penumpang trayek L1 Terminal Brawijaya - Terminal Blambangan (Via Jl. Jend. A. Yani). Setiap kali beroperasi rata rata 5 kali pergi pulang atau 10 rit perjalanan/hari. 
Bagaimanakah operasional angkutan umum penumpang trayek L1 Terminal Brawijaya - Terminal Blambangan ( Via Jl. Jend. A. Yani ) pada saat ini (2015).

Operasional pelayanan Angkutan Umum Penumpang trayek L1 Terminal Brawijaya Terminal Brawijaya ( Via Jl. Jend. A. Yani ) saat ini.

\section{Angkutan Umum Penumpang (AUP)}

Angkutan umum penumpang adalah angkutan penumpang yang dilakukan dengan sistem sewa atau bayar. Termasuk dalam pengertian dalam angkutan umum penumpang adalah bus, mini bus, mikrolet, kereta api, angkutan air dan angkutan darat. Warpani (1990)

Menurut Warpani (1990), pengadaan pelayanan AUP memang secara langsung mengurangi banyaknya kendaraan pribadi, namun AUP bukan salah satu jalan keluar untuk menyelesaikan masalah lalu-lintas kota. Pelayanan AUP akan berjalan baik apabila tercipta keseimbangan antara penyediaan dan permintaan.

\section{Kinerja Angkutan}

Indikator kualitas pelayanan operasi angkutan dapat dilihat dari nilai kinerja operasi yang dihasilkan, parameter yang digunakan frekuensi, headway, Load factor, kecepatan perjalanan dan waktu tempuh Asikin (2001).

Frekuensi adalah jumlah kendaraan yang lewat per satuan waktu Morlok (1978). Frekuensi dapat dirumuskan sebagai berikut :

$$
\mathrm{F}=1 / \mathrm{h}
$$

Dimana :

$$
\begin{aligned}
& \mathrm{F}=\text { frekuensi } \\
& \mathrm{h}=\text { headway (menit) }
\end{aligned}
$$

Headway adalah waktu antara satu kendaraan dengan kendaraan lain yang berurutan dibelakangny pada satu rute yang sama Asikin (2001). Nilai headway dirumuskan sebagai berikut :

$$
\mathrm{Ht}=\frac{60}{\mathrm{Q} / \mathrm{jam}}
$$

Dimana:

$$
\begin{aligned}
& \text { Q/jam = jumlah kendaraan dalam satu } \\
& \text { jam } \\
& \mathrm{Ht}=\text { headway (menit) }
\end{aligned}
$$

Load factor (LF) merupakan perbandingan antara kapasitas terjual dan kapasitas tersedia untuk satu perjalanan yang biasa dinyatakan dalam persen (\%) (Abubakar,1995:182).

$$
\mathrm{LF}=\frac{\mathrm{JF}}{\mathrm{C}} \mathrm{x} 100 \%
$$

Dimana :

$$
\begin{aligned}
& \mathrm{LF}=\text { Load factor }(\%) \\
& \mathrm{JF}=\text { Banyaknya penumpang yang diangkut } \\
& \text { sepanjang satu lintasan per trip. } \\
& \mathrm{C}=\text { kapasitas kendaraan. }
\end{aligned}
$$

Menurut Direktorat Jendral Perhubungan Darat (1995), bahwa nilai Load factor dalam kondisi dinamis $70 \%$.

Menurut Morlok (1978) menyatakan bahwa kecepatan perjalanan yaitu kecepatan kendaraan dari awal ruteke titik akhir rute, dan dirumuskan dengan :

$$
\mathrm{V}=\mathrm{S} / \mathrm{t}
$$

Dimana :

$$
\begin{aligned}
& \mathrm{V}=\text { Kecepatan tempuh angkutan umum } \\
& \text { (Km/jam) } \\
& \mathrm{S}=\text { Jarak Tempuh Angkutan Umum } \\
& (\mathrm{Km}) \\
& \mathrm{t}=\text { Waktu Tempuh Angkutan Umum } \\
& \text { (Jam) }
\end{aligned}
$$




\section{METODE PENELITIAN}

\section{Lokasi Studi}

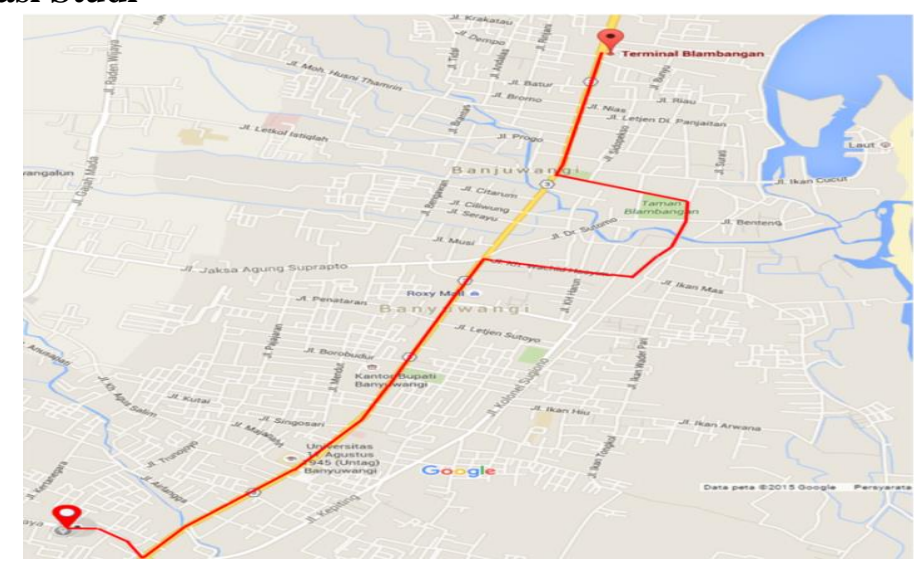

Keterangan :

L1 dari Terminal Brawijaya Terminal Blambangan

\section{L1 dari Terminal}

Blambangan - Terminal

Brawijaya

Gambar 1. Peta Lokasi Studi Kota Banyuwangi

\section{Rute Terminal Blambangan - Terminal \\ Brawijaya :}

Terminal Brawijaya - Jl. Brawijaya - Jl. Adi Sucipto - Jl. A. Yani P.B Sudirman - Jl. Jendral Basuki Rahmat - Jl. Di Panjaitan - Jl. Kartini - Jl. Dr Wahidin Sudiro Husodo - Jl. Jend. A. Yani (Roxy Supermarket) - Jl. Dr. Sutomo - Jl. Basuki Rahmad - Jl. Sritanjung - Terminal Blambangan.

\section{Terminal Blambangan - Terminal \\ Brawijaya :}

Terminal Blambangan - Jl. Sritanjung - Jl. Basuki Rahmad - Jl. Di Panjaitan - Jl. Kartini - Jl. Dr Wahidin Sudiro Husodo - Jl. Dr.Sutomo - Jl. Jendral A. Yani (Roxy Supermarket) - J1. A. Yani P.B Sudirman Jl. Jendral Basuki Rahmat -Jl. Adi Sucipto Jl. Brawijaya - Terminal Brawijaya.

\section{Tahapan Studi}

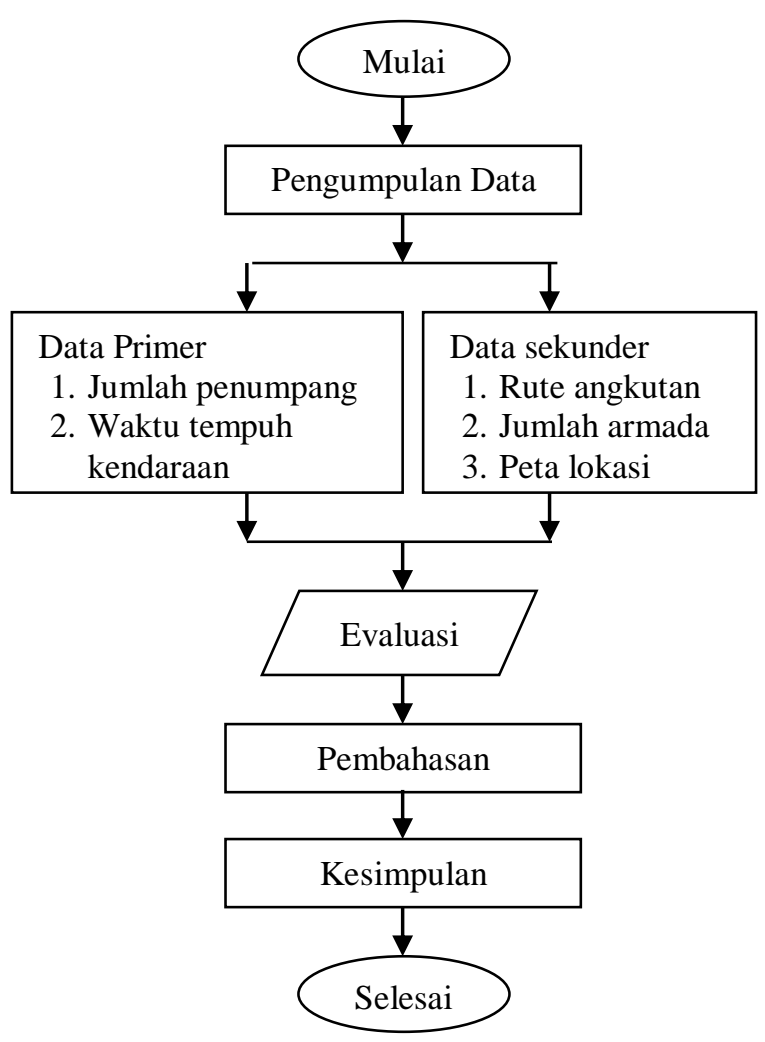

Gambar 2. Diagram Alir Penelitian

\section{HASIL DAN PEMBAHASAN}

Panjang rute AUP Trayek L1 Terminal Brawijaya - Terminal Blambangan maupun arah Terminal Blambangan - Terminal Brawijaya adalah $\pm 18 \mathrm{~km}$.
Data penumpang, data pola naik turun penumpang, data waktu tempuh AUP Trayek L1 Terminal Brawijaya - Terminal Blambangan dari survey disajikan pada tabel 1, tabel 2, tabel 3 dan tabel 4 . 
Tabel 1. Data Penumpang AUP Trayek L1 Terminal Brawijaya - Terminal Blambangan.

\begin{tabular}{ccccccccccccc}
\hline \multicolumn{4}{c}{ Terminal Brawijaya - Terminal Blambangan } & \multicolumn{4}{c}{ Terminal Blambangan - Terminal Brawijaya } \\
\hline $\begin{array}{c}\text { Jam } \\
\text { berangkat }\end{array}$ & Senin & Selasa & Rabu & Kamis & Sabtu & Minggu & Senin & Selasa & Rabu & Kamis & Sabtu & Minggu \\
\hline 06.00 & 7 & 5 & 8 & 4 & 5 & 4 & 4 & 5 & 5 & 6 & 5 & 4 \\
06.30 & 9 & 9 & 9 & 6 & 7 & 8 & 9 & 6 & 5 & 4 & 6 & 5 \\
07.00 & 8 & 6 & 8 & 9 & 7 & 9 & 7 & 8 & 8 & 9 & 7 & 6 \\
08.00 & 6 & 5 & 8 & 8 & 4 & 4 & 5 & 5 & 4 & 4 & 3 & 5 \\
08.30 & 5 & 7 & 5 & 8 & 5 & 5 & 3 & 5 & 6 & 5 & 5 & 8 \\
10.00 & 8 & 5 & 6 & 6 & 6 & 6 & 4 & 6 & 7 & 4 & 6 & 7 \\
11.00 & 7 & 6 & 6 & 5 & 7 & 9 & 5 & 4 & 6 & 7 & 9 & 6 \\
12.00 & 5 & 6 & 5 & 6 & 6 & 5 & 3 & 4 & 8 & 6 & 5 & 6 \\
12.30 & 6 & 4 & 7 & 4 & 8 & 7 & 6 & 4 & 6 & 5 & 6 & 5 \\
13.00 & 11 & 10 & 8 & 8 & 9 & 6 & 6 & 7 & 7 & 9 & 9 & 8 \\
13.30 & 9 & 9 & 10 & 6 & 8 & 7 & 3 & 8 & 5 & 6 & 7 & 9 \\
14.00 & 4 & 7 & 5 & 3 & 6 & 5 & 4 & 6 & 6 & 5 & 8 & 5 \\
15.00 & 6 & 5 & 5 & 6 & 5 & 4 & 6 & 8 & 5 & 5 & 5 & 6 \\
16.00 & 5 & 4 & 4 & 5 & 5 & 4 & 4 & 6 & 4 & 4 & 4 & 5 \\
17.00 & 4 & 5 & 4 & 4 & 4 & 3 & 3 & 4 & 3 & 3 & 3 & 4 \\
18.00 & 4 & 5 & 3 & 5 & 3 & 3 & 3 & 3 & 4 & 4 & 4 & 4 \\
\hline
\end{tabular}

Data pola naik turun penumpang contoh diambil pada hari Senin berdasarkan jumlah pada Tabel 2 dan 3

Tabel 2. Pola Naik Turun Penumpang AUP trayek L1 Arah Terminal Brawijaya - Terminal Blambangan

\begin{tabular}{|c|c|c|c|c|c|c|c|c|c|c|c|c|}
\hline No & Waktu & $\begin{array}{c}\text { No polisi } \\
\text { kendaraan }\end{array}$ & Zona & 1 & 2 & 3 & 4 & 5 & 6 & 7 & Tot & Maks \\
\hline \multirow[t]{3}{*}{1} & 06.00 & P 1050 UV & Naik & - & 3 & 2 & - & 1 & 1 & - & 7 & \\
\hline & & & Turun & - & - & - & - & 4 & 2 & 1 & 7 & \\
\hline & & & Jumlah & - & 3 & 5 & 5 & 2 & 1 & 1 & & 5 \\
\hline \multirow[t]{3}{*}{2} & 06.30 & P 375 UV & Naik & 2 & 1 & - & 1 & - & - & - & 9 & \\
\hline & & & Turun & - & - & - & 2 & - & - & - & 9 & \\
\hline & & & Jumlah & 2 & 5 & 8 & 7 & 2 & 2 & - & & 8 \\
\hline \multirow[t]{3}{*}{3} & 07.00 & P 418 UV & Naik & 2 & 4 & 1 & - & - & - & - & 8 & \\
\hline & & & Turun & - & - & - & 2 & - & 1 & 3 & 8 & \\
\hline & & & Jumlah & 2 & 6 & 8 & 6 & 4 & 3 & 3 & & 8 \\
\hline \multirow[t]{3}{*}{4} & 08.00 & P 668 UV & Naik & - & 2 & 2 & 1 & 1 & - & - & 6 & \\
\hline & & & Turun & - & - & - & - & 3 & - & 3 & 6 & \\
\hline & & & Jumlah & - & 2 & 4 & 5 & 3 & 3 & 3 & & 5 \\
\hline \multirow[t]{3}{*}{5} & 08.30 & P 2662 UV & Naik & - & 1 & 2 & - & 2 & - & - & 5 & \\
\hline & & & Turun & - & - & - & - & 1 & 3 & 1 & 5 & \\
\hline & & & Jumlah & - & 1 & 3 & - & 4 & 1 & 1 & & 4 \\
\hline \multirow[t]{3}{*}{6} & 10.00 & P 623 UV & Naik & 3 & 1 & 2 & 3 & - & - & - & 8 & \\
\hline & & & Turun & - & - & - & - & 3 & 4 & 2 & 8 & \\
\hline & & & Jumlah & 3 & 4 & 6 & 9 & 6 & 2 & 2 & & 9 \\
\hline \multirow[t]{3}{*}{7} & 11.00 & P 845 UV & Naik & 3 & - & 2 & - & 2 & - & - & 7 & \\
\hline & & & Turun & - & 1 & - & 3 & - & 2 & 1 & 7 & \\
\hline & & & Jumlah & 3 & 2 & 4 & 1 & 3 & 1 & 1 & & 4 \\
\hline \multirow[t]{3}{*}{8} & 12.00 & P 365 UV & Naik & 2 & 1 & - & - & 2 & - & - & 5 & \\
\hline & & & Turun & - & - & - & 2 & - & 3 & 1 & 5 & \\
\hline & & & Jumlah & 2 & 3 & 3 & 1 & 4 & 1 & 1 & & 4 \\
\hline \multirow[t]{3}{*}{9} & 12.30 & P 368 UV & Naik & - & 2 & 1 & - & 2 & 1 & - & 6 & \\
\hline & & & Turun & - & - & - & 1 & 1 & 2 & 2 & 6 & \\
\hline & & & Jumlah & - & 2 & 3 & 2 & 3 & 2 & 2 & & 3 \\
\hline
\end{tabular}

Survey pada hari Senin, 22 juni 2015 
Lanjutan Tabel 2. Pola Naik Turun Penumpang AUP trayek L1 Arah Terminal Brawijaya Terminal Blambangan

\begin{tabular}{|c|c|c|c|c|c|c|c|c|c|c|c|c|}
\hline No & Waktu & $\begin{array}{c}\text { No polisi } \\
\text { kendaraan }\end{array}$ & Zona & 1 & 2 & 3 & 4 & 5 & 6 & 7 & Tot & Maks \\
\hline \multirow[t]{3}{*}{10} & 13.00 & P 1020 UV & Naik & 1 & 4 & 3 & - & - & - & - & 11 & \\
\hline & & & Turun & - & - & 1 & - & - & - & - & 11 & \\
\hline & & & Jumlah & 1 & 5 & 7 & 8 & 8 & 3 & 3 & & 8 \\
\hline \multirow[t]{3}{*}{11} & 13.30 & P 1043 UV & Naik & 2 & - & 3 & 1 & - & - & - & 9 & \\
\hline & & & Turun & - & - & - & 2 & - & 2 & 2 & 9 & \\
\hline & & & Jumlah & 2 & 5 & 8 & 5 & 4 & 2 & 2 & & 8 \\
\hline \multirow[t]{3}{*}{12} & 14.00 & P 994 UV & Naik & - & 1 & 2 & - & 1 & - & - & 4 & \\
\hline & & & Turun & - & - & - & 1 & - & 3 & - & 4 & \\
\hline & & & Jumlah & - & 1 & 3 & 2 & 3 & 3 & - & & 3 \\
\hline \multirow[t]{3}{*}{13} & 15.00 & P 542 UV & Naik & 2 & - & 1 & - & 2 & 1 & - & 6 & \\
\hline & & & Turun & - & - & - & 1 & 1 & 2 & 2 & 6 & \\
\hline & & & Jumlah & 2 & 2 & 3 & 2 & 3 & 2 & 2 & & 3 \\
\hline \multirow[t]{3}{*}{14} & 16.00 & P 582 UV & Naik & - & 2 & - & 2 & - & 1 & - & 5 & \\
\hline & & & Turun & - & - & 1 & - & 2 & - & 2 & 5 & \\
\hline & & & Jumlah & - & 2 & 1 & 3 & 1 & 2 & 2 & & 3 \\
\hline \multirow[t]{3}{*}{15} & 17.00 & P 1021 UV & Naik & - & - & 2 & - & 2 & - & - & 4 & \\
\hline & & & Turun & - & - & - & 1 & - & 2 & 1 & 4 & \\
\hline & & & Jumlah & - & - & 2 & 1 & 3 & 1 & 1 & & 3 \\
\hline \multirow[t]{3}{*}{16} & 18.00 & P 1024 UV & Naik & 2 & - & - & 1 & 1 & - & - & 4 & \\
\hline & & & Turun & - & - & 1 & - & 1 & 2 & - & 4 & \\
\hline & & & Jumlah & 2 & 2 & 1 & 2 & 2 & 2 & - & & 2 \\
\hline
\end{tabular}

Tabel 3. Pola Naik Turun Penumpang AUP trayek L1 Arah Terminal Blambangan Terminal Brawijaya Hari Senin, 22 juni 2015

\begin{tabular}{|c|c|c|c|c|c|c|c|c|c|c|c|c|}
\hline No & Waktu & $\begin{array}{l}\text { No polisi } \\
\text { kendaraan }\end{array}$ & Zona & 1 & 2 & 3 & 4 & 5 & 6 & 7 & Tot & Maks \\
\hline \multirow{3}{*}{1} & 06.00 & P 843 UV & Naik & 1 & 1 & - & 2 & - & - & - & 4 & \\
\hline & & & Turun & - & - & - & - & 1 & 2 & 1 & 4 & \\
\hline & & & Jumlah & 1 & 2 & 2 & 4 & 3 & 1 & 1 & & 4 \\
\hline \multirow[t]{3}{*}{2} & 06.30 & P 570 UV & Naik & 4 & - & 3 & - & - & - & - & 9 & \\
\hline & & & Turun & - & - & - & 4 & 3 & - & - & 9 & \\
\hline & & & Jumlah & 4 & 6 & 9 & 5 & 2 & 2 & - & & 9 \\
\hline \multirow[t]{3}{*}{3} & 07.00 & P 902 UV & Naik & 2 & 1 & 1 & - & - & - & - & 7 & \\
\hline & & & Turun & - & - & 2 & - & 2 & - & - & 7 & \\
\hline & & & Jumlah & 2 & 3 & 6 & 5 & 5 & 1 & 1 & & 6 \\
\hline \multirow[t]{3}{*}{4} & 08.00 & P 973 UV & Naik & 2 & - & - & 3 & - & - & - & 5 & \\
\hline & & & Turun & - & - & - & 1 & 2 & - & 2 & 5 & \\
\hline & & & Jumlah & 2 & 2 & 2 & 2 & 2 & 4 & 2 & & 4 \\
\hline \multirow[t]{3}{*}{5} & 08.30 & P 986 UV & Naik & - & 1 & 1 & 1 & - & - & - & 3 & \\
\hline & & & Turun & - & - & - & - & 2 & 1 & - & 3 & \\
\hline & & & Jumlah & - & - & 1 & 1 & 2 & 3 & 1 & & 2 \\
\hline \multirow[t]{3}{*}{6} & 10.00 & P 860 UV & Naik & - & 2 & - & 1 & 1 & - & - & 4 & \\
\hline & & & Turun & - & - & 1 & - & - & 2 & 1 & 4 & \\
\hline & & & Jumlah & - & - & 2 & 1 & 2 & 3 & 1 & & 3 \\
\hline \multirow[t]{3}{*}{7} & 11.00 & P 378 UV & Naik & 2 & - & 1 & 1 & 1 & - & - & 5 & \\
\hline & & & Turun & - & - & 1 & - & 2 & - & 1 & 5 & \\
\hline & & & Jumlah & 2 & 2 & 2 & 2 & 2 & 3 & 1 & & 3 \\
\hline \multirow[t]{3}{*}{8} & 12.00 & P 1053 UV & Naik & - & 2 & - & - & 1 & - & - & 3 & \\
\hline & & & Turun & - & - & - & - & - & - & 3 & 3 & \\
\hline & & & Jumlah & - & - & 2 & 2 & 2 & 3 & 3 & & 3 \\
\hline \multirow[t]{3}{*}{9} & 12.30 & P 786 UV & Naik & 2 & 1 & 2 & - & 1 & - & - & 6 & \\
\hline & & & Turun & - & - & 1 & - & 1 & 2 & 2 & 6 & \\
\hline & & & Jumlah & 2 & 2 & 2 & 3 & 4 & 4 & 4 & & 4 \\
\hline
\end{tabular}


Lanjutan Tabel 3. Pola Naik Turun Penumpang AUP trayek L1 Arah Terminal Blambangan Terminal Brawijaya Hari Senin, 22 juni 2015

\begin{tabular}{|c|c|c|c|c|c|c|c|c|c|c|c|c|}
\hline \multirow[b]{2}{*}{ No } & \\
\hline & Waktu & $\begin{array}{l}\text { No polisi } \\
\text { kendaraan }\end{array}$ & Zona & 1 & 2 & 3 & 4 & 5 & 6 & 7 & Tot & Maks \\
\hline \multirow[t]{3}{*}{10} & 13.00 & P 558 UV & Naik & - & 4 & 2 & - & - & - & - & 6 & \\
\hline & & & Turun & - & - & - & - & 4 & 1 & 1 & 6 & \\
\hline & & & Jumlah & - & - & 4 & 6 & 6 & 2 & 1 & & 6 \\
\hline \multirow[t]{3}{*}{11} & 13.30 & P 1254 UV & Naik & - & - & 2 & 1 & - & - & - & 3 & \\
\hline & & & Turun & - & - & - & - & - & 1 & 2 & 3 & \\
\hline & & & Jumlah & - & - & - & 2 & 2 & 3 & 2 & & 3 \\
\hline \multirow[t]{3}{*}{12} & 14.00 & P 1067 UV & Naik & 1 & 1 & 2 & - & - & - & - & 4 & \\
\hline & & & Turun & - & - & 1 & - & 1 & - & 2 & 4 & \\
\hline & & & Jumlah & 1 & 1 & 1 & 2 & 3 & 3 & 2 & & 3 \\
\hline \multirow[t]{3}{*}{13} & 15.00 & P 487 UV & Naik & - & 2 & 1 & 2 & 1 & - & - & 6 & \\
\hline & & & Turun & - & - & - & 1 & 1 & 2 & 2 & 6 & \\
\hline & & & Jumlah & - & - & 2 & 2 & 3 & 4 & 4 & & 4 \\
\hline \multirow[t]{3}{*}{14} & 16.00 & P 899 UV & Naik & - & 2 & 1 & - & 1 & - & - & 4 & \\
\hline & & & Turun & - & - & - & 1 & - & 2 & 1 & 4 & \\
\hline & & & Jumlah & - & - & 2 & 2 & 3 & 2 & 3 & & 3 \\
\hline \multirow[t]{3}{*}{15} & 17.00 & P 1042 UV & Naik & - & 1 & 1 & - & 1 & - & - & 3 & \\
\hline & & & Turun & - & - & - & - & - & - & 3 & 3 & \\
\hline & & & Jumlah & - & - & 1 & 1 & 2 & 2 & 3 & & 3 \\
\hline \multirow[t]{3}{*}{16} & 18.00 & P 876 UV & Naik & - & - & 2 & - & 1 & - & - & 3 & \\
\hline & & & Turun & - & - & - & - & - & 2 & 1 & 3 & \\
\hline & & & Jumlah & - & - & - & 2 & 2 & 2 & 3 & & 2 \\
\hline
\end{tabular}

Data waktu tempuh AUP Trayek L1 Terminal Brawijaya - Terminal Blambangan disajikan pada tabel 4 .

Tabel 4. Data waktu Tempuh AUP Trayek L1(Menit)

\begin{tabular}{ccccccccccccc}
\hline Jam & \multicolumn{9}{c}{ Terminal Brawijaya - Terminal Blambangan } & \multicolumn{7}{c}{ Terminal Blambangan - Terminal Brawijaya } \\
Berangkat & Senin & Selasa & Rabu & Kamis & Sabtu & Minggu & Senin & Selasa & Rabu & Kamis & Sabtu & Minggu \\
\hline 06.00 & 52 & 53 & 50 & 57 & 55 & 48 & 48 & 50 & 57 & 56 & 49 & 53 \\
06.30 & 55 & 50 & 53 & 55 & 57 & 52 & 54 & 53 & 56 & 54 & 54 & 56 \\
07.00 & 57 & 52 & 54 & 58 & 54 & 54 & 56 & 56 & 55 & 55 & 48 & 49 \\
08.00 & 56 & 54 & 52 & 55 & 56 & 53 & 49 & 54 & 54 & 56 & 55 & 47 \\
08.30 & 58 & 53 & 56 & 57 & 58 & 58 & 53 & 55 & 57 & 58 & 56 & 54 \\
10.00 & 62 & 57 & 58 & 58 & 54 & 56 & 55 & 54 & 58 & 56 & 58 & 53 \\
11.00 & 57 & 62 & 61 & 63 & 58 & 55 & 57 & 58 & 59 & 57 & 53 & 56 \\
12.00 & 56 & 58 & 55 & 59 & 61 & 49 & 55 & 57 & 60 & 56 & 54 & 55 \\
12.30 & 51 & 55 & 53 & 58 & 59 & 59 & 58 & 49 & 56 & 55 & 56 & 54 \\
13.00 & 49 & 53 & 50 & 54 & 56 & 57 & 59 & 57 & 58 & 59 & 57 & 48 \\
13.30 & 50 & 47 & 53 & 55 & 54 & 54 & 56 & 56 & 61 & 59 & 58 & 58 \\
14.00 & 57 & 54 & 57 & 58 & 56 & 58 & 58 & 56 & 59 & 58 & 55 & 56 \\
15.00 & 62 & 63 & 58 & 56 & 59 & 59 & 57 & 58 & 56 & 57 & 56 & 57 \\
16.00 & 59 & 58 & 59 & 62 & 60 & 61 & 58 & 62 & 62 & 58 & 59 & 59 \\
17.00 & 63 & 62 & 60 & 57 & 58 & 63 & 63 & 60 & 60 & 60 & 60 & 60 \\
18.00 & 62 & 65 & 58 & 59 & 65 & 60 & 59 & 58 & 64 & 65 & 61 & 61 \\
\hline
\end{tabular}

\section{Kinerja AUP L1}

Load factor angkutan umum penumpang dihitung berdasarkan data penumpang, hasil perhitungan Load factor \&
Pasengger on vhicle (POV) AUP trayek L1 Terminal Brawijaya - Terminal Blambangan disajikan pada tabel 5 . 
Tabel 5. Load factor \& Passenger on vhicle AUP trayek L1.

\begin{tabular}{lcccc}
\hline \multicolumn{2}{c}{ Load Factor (\%) } & \multicolumn{2}{c}{ Passenger on vhicle (POV) } \\
\hline Arah & BR - BL & BL - BR & BR - BL & BL - BR \\
Maksimum & 91,66 & 75,00 & 10 & 9 \\
Minimum & 25,00 & 25,00 & 2 & 2 \\
Rata-rata & 50,77 & 45,90 & 4,65 & 10 \\
Maksimum & & 91,66 & & 2 \\
Minimum & 25,00 & & 4,41 \\
Rata-rata & 48,33 & & \\
BR = Terminal Brawijaya BL = Terminal Blambangan & & \\
Sumber : Hasil Perhitungan &
\end{tabular}

Frekuensi dan Headway AUP Trayek L1 Terminal Brawijaya - Terminal Blambangan berdasarkan data jumlah kendaraan, frekuensi rata-rata dan headway (waktu) rata-rata disajikan pada tabel 6.

Tabel 6. Frekuensi \& Headway AUP trayek L1.

\begin{tabular}{|c|c|c|c|c|}
\hline \multirow[b]{2}{*}{ Arah } & \multicolumn{2}{|c|}{ Frekuensi (kend/jam) } & \multicolumn{2}{|c|}{ Headway (menit) } \\
\hline & $\mathrm{BR}-\mathrm{BL}$ & $B L-B R$ & BR - BL & BL - BR \\
\hline Maksimum & 35 & 34 & 3,33 & 3,15 \\
\hline Minimum & 18 & 19 & 1,71 & 1,76 \\
\hline Rata-rata & 26,17 & 26,17 & 2,48 & 2,44 \\
\hline Maksimum & \multicolumn{2}{|c|}{35} & \multicolumn{2}{|c|}{3,33} \\
\hline Minimum & \multicolumn{2}{|c|}{18} & \multicolumn{2}{|c|}{1,71} \\
\hline Rata-rata & \multicolumn{2}{|c|}{26,17} & \multicolumn{2}{|c|}{2,46} \\
\hline
\end{tabular}

Waktu tempuh AUP Trayek L1 Terminal Brawijaya - Terminal Blambangan berdasarkan data waktu tempuh (tabel 4) dan Kecepatan Tempuh AUP Trayek L1 disajikan pada tabel 7.

Tabel 7. Waktu Tempuh (menit/km) \& Kecepatan Tempuh AUP Trayek L1.

\begin{tabular}{|c|c|c|c|c|}
\hline & \multicolumn{2}{|c|}{ Waktu Tempuh (Menit/Km) } & \multicolumn{2}{|c|}{ Kecepatan tempuh (Km/Jam) } \\
\hline Arah & $B R-B L$ & $B L-B R$ & $B R-B L$ & $B L-B R$ \\
\hline Maksimum & 3,60 & 3,60 & 23,07 & 22,50 \\
\hline Minimum & 2,60 & 2,60 & 16,66 & 16,66 \\
\hline Rata-rata & 3,15 & 3,20 & 19,34 & 19,25 \\
\hline Maksimum & \multicolumn{2}{|c|}{3,60} & \multicolumn{2}{|c|}{23,07} \\
\hline Minimum & \multicolumn{2}{|c|}{2,60} & \multicolumn{2}{|c|}{16,66} \\
\hline Rata-rata & \multicolumn{2}{|c|}{3,20} & \multicolumn{2}{|c|}{19,30} \\
\hline
\end{tabular}

\section{Pembahasan}

Load factor arah Terminal Brawijaya Terminal Blambangan, angkutan umum penumpang Trayek L1 Load factor tertinggi sebesar $91,66 \%$ pada jam keberangkatan 13.00 WIB, Load factor terendah sebesar $25,00 \%$ pada jam keberangkatan 18.00 WIB dan pada hari Minggu kegiatan akhir pekan masyarakat, Load factor tertinggi sebesar $75,00 \%$ yaitu terjadi pada keberangkatan 07.00 WIB dan 11.00 WIB dan Load factor terendah $25,00 \%$ pada keberangkatan 17.00 WIB dan 18.00 WIB. Sedangkan Load factor arah Terminal Blambangan - Terminal Brawijaya, Load factor tertinggi sebesar 75.00\% pada jam keberangkatan 06.30, 07.00 dan 13.00 WIB, Load factor terendah sebesar 25,00\% terjadi jam keberangkatan 17.00 dan 18.00 WIB dan pada hari minggu kegiatan akhir pekan masyarakat, Load factor tertinggi sebesar $75,00 \%$ yaitu terjadi pada keberangkatan 13.30 WIB dan Load factor 
terendah sebesar 33,33\% pada keberangkatan 06.00, 17.00 dan 18.00 WIB. Untuk Load factor rata - rata kedua arah sebesar 48,33\% ( 5,5 pnp/trip.kend) untuk mengetahui tingkat keterisian kapasitas penumpang tidak melebihi kapasitas yang ditentukan yaitu < $70 \%$. Pola naik turun penumpang atau passenger on vhicle (POV) penumpang Terminal Brawijaya - Terminal Blambangan jumlah penumpang sebesar 10 penumpang, pada hari minggu jumlah penumpang tertinggi sebesar 7 penumpang dengan rata rata 4,65 penumpang, sedangkan Terminal Blambangan - Terminal Brawijaya jumlah penumpang sebesar 9 penumpang, pada hari Minggu jumlah penumpang tertinggi 8 penumpang dengan rata - rata 4,18 penumpang. Rata - rata untuk kedua arah yaitu 4,41 penumpang, untuk kapasitas AUP L1 masih tergolong nyaman dari kapasitas angkutan umum penumpang yang berjumlah 12 penumpang.

Pada arah Terminal Brawijaya Terminal Blambangan angkutan umum penumpang frekuensi maksimum sebesar 35 kend/jam dan headway minimum 1,71 menit, terdapat frekuensi minimum sebesar 18 $\mathrm{kend} / \mathrm{jam}$ dan headway maksimum sebesar 3,33 menit. Pada hari Minggu kegiatan akhir pekan masyarakat frekuensi maksimum sebesar $32 \mathrm{kend} / \mathrm{jam}$ dan headway minimum sebesar 1,87 menit, frekuensi minimum sebesar 21 kend/jam dan headway maksimum sebesar 2,85 menit. Rata - rata frekuensi 26,17 kend/jam dan headway 2,46 menit. Sedangkan untuk arah arah Terminal Blambangan - Terminal Brawijaya frekuensi dan headway angkutan umum penumpang frekuensi maksimum 34 kend/jam dan headway minimum 1,76 menit, terdapat frekuensi minimum 19 kend/jam dan Headway maksimum 3,15 menit Pada hari Minggu kegiatan akhir pekan masyarakat frekuensi maksimum $34 \mathrm{kend} / \mathrm{jam}$ dan headway minimum 1,76 menit dan frekuensi minimum 19 kend/jam dan headway maksimum 3,15 menit. Untuk rata - rata frekuensi $26,17 \mathrm{kend} / \mathrm{jam}$ dan headway 2,44 menit.

Frekuensi maksimum untuk kedua arah $35 \mathrm{kend} / \mathrm{jam}$ dengan headway minimum kedua arah 1,71 menit sedangkan frekuensi minimum kedua arah $18 \mathrm{kend} / \mathrm{jam}$ dengan headway maksimum 3,33 menit dan frekuensi rata - rata kedua arah 26,17 kend/jam dengan headway rata - rata kedua arah 2,46 menit. Headway rata - rata 2,46 menit dipengaruhi oleh jumlah armada yang beroperasi yaitu 32 unit untuk para penumpang dengan waktu tunggu yang tidak lama untuk mendapatkan angkutan umum penumpang selanjutnya.

Jumlah armada yang beroperasi saat ini hasil evaluasi yang dilakukan, headway angkutan umum penumpang terminal Brawijaya - terminal Blambangan adalah 2,46 menit dan passenger on vehicle (POV) maksimum 10 penumpang dengan rata - rata 4,25 menit penumpang untuk kedua arah. Dengan kondisi yang demikian, penumpang tidak memerlukan waktu tunggu yang lama untuk mengisi angkutan selanjutnya.

Kecepatan tempuh angkutan umum penumpang Trayek L1 arah Terminal Brawijaya - Terminal Blambangan, kecepatan tempuh maksimum sebesar 23,07 $\mathrm{Km} / \mathrm{jam}$ dengan waktu tempuh 47 menit ekuivalen 3,00 Menit/Km sedangkan kecepatan tempuh minimum sebesar 16,66 $\mathrm{Km} / \mathrm{jam}$ dengan data waktu tempuh 65 menit ekuivalen 3,60 Menit/Km untuk arah Terminal Blambangan - Terminal Brawijaya, kecepatan tempuh maksimum sebesar 22,50 $\mathrm{Km} / \mathrm{jam}$ dengan data waktu tempuh 48 menit ekuivalen 2,67 Menit/Km sedangkan kecepatan tempuh minimum sebesar 16,66 $\mathrm{Km} / \mathrm{jam}$ dengan data waktu tempuh 65 menit ekuivalen 3,60 Menit/Km. Kecepatan tempuh dan waktu tempuh Untuk kedua arah sebesar 23,07 Km/jam ekuivalen 3,00 menit/Km sedangkan untuk minimum sebesar 16,66 $\mathrm{Km} / \mathrm{jam}$ ekuivalen 3,60 Menit/Km, kecepatan tempuh dan waktu tempuh rata rata kedua arah sebesar 19,30 $\mathrm{Km} / \mathrm{jam}$ dengan waktu tempuh $3,11 \mathrm{menit} / \mathrm{Km}$.

\section{Produktivitas.}

Berdasarkan jumlah kendaraan yang beroperasi yaitu 32 unit, angkutan umum penumpang trayek L1 Terminal Brawijaya Terminal Blambangan yang beroperasi pada pukul 06.00 WIB -21.00 WIB diakumulasikan dengan jumlah trip angkutan setiap harinya yaitu 337 trip/hari dengan rata - rata trip/kend sebesar 10,27 trip/kend, berdasarkan Jumlah penumpang rata - rata sebesar 5,5 pnp/kend-trip dan waktu operasi 6 hari/Minggu (313 hari/thn) dengan kapasitas kendaraan 12 penumpang/kend. 
Kapasitas jumlah penumpang yang dilayani sebesar 3943 pnp/hari ekuivalen 1234159 pnp/tahun sedangkan untuk jumlah penumpang 1906 pnp/hari ekuivalen 596578 pnp/ tahun, dengan demikian adala selisih jumlah 2040 penumpang/hari atau sebesar 637581 pnp/tahun, peminat masih rendah untuk menggunakan jasa angkutan umum penumpang trayek L1. Dengan demikian perlu dilakukan tinjauan ketersedian armada angkutan

\section{Ketersediaan angkutan}

Ketersedian armada angkutan umum penumpang trayek L1 penumpang sebesar 1906 penumpang/hari dengan okupansi $70 \%$ produktivitas AUP 10 trip/hari diperoleh 80 penumpang/hari-kend, yaitu Jumlah penumpang dan Kapasitas ideal angkutan umum penumpang. Ketersediaan angkutan umum penumpang trayek L1 dengan jumlah armada 32 unit maka didapat jumlah kebutuhan armada yang optimal sebesar 24 kendaraan perhari dengan nilai headway sebesar 4,66 menit.

\section{KESIMPULAN}

Kinerja angkutan umum penumpang Trayek L1 terminal Brawijaya - Terminal Blambangan pada tahun 2015, Load factor rata-rata 48,33\%, Passenger on vhicle (POV) rata - rata 4,41 penumpang, headway (waktu) rata-rata 2,46 menit, waktu tempuh rata-rata 3,11 menit/km, produktivitas 2040 pnp/kend.hari

\section{DAFTAR PUSTAKA}

Keputusan Direktorat Jenderal Perhubungan Darat No. SK.678/AJ.206/2002 Tentang Pedoman Teknis Penyelenggaraan Angkutan Penumpang Umum Di Wilayah Perkotaan dalam Trayek Tetap dan Teratur.

Direktorat Jenderal Perhubungan Darat. 1996. Pedoman Teknis Penyelenggaraan Angkutan Penumpang Umum Di Wilayah Perkotaan Dalam Trayek Tetap dan Teratur.

Abubakar, Iskandar Ir. Dkk. 1995. Мепији Lalu Lintas dan Angkutan Jalan Yang Tertib, Direktorat Jenderal Perhubungan Darat, Jakarta.
Asikin, Muslich Z. 2001. Sistem Manajemen Transportasi Kota. Yogjakarta : Philosophy Prees.

Munawar, Ahmad. 2005. Dasar - Dasar Teknik Transportasi. Jogjakarta : Beta Offset.

Morlok, Edward K. 1978. Pengantar Teknik dan Perencanaan Transportasi. Terjemahan oleh Johan K.Hainim. 1995. Jakarta : Erlangga.

Nasution, M. Noer. 1996. Manajemen Transportasi. Jakarta : Penerbitan Ghalia Indonesia.

Salim Abbas, A.H. 1993. Manajemen Transportasi. Jakarta : PT. Raja Grafindo Persada.

Warpani, Suwardjoko. 1990. Merencanakan Sistem Perangkutan. Bandung : Penerbit ITB.

Warpani, Suwardjoko. 2002. Pengelolaan Lalu Lintas dan Angkutan Jalan. Bandung :Penerbit ITB 